\title{
TTR
}

Traduction, terminologie, re?daction

\section{Byron Lands in Korea: Translation and Literary/Cultural Changes in Early Twentieth-Century Korea}

\section{Theresa Hyun}

Volume 10, numéro 1, 1er semestre 1997

Langues, traduction et post-colonialisme

Languages, Translation and Post-Colonialism

URI : https://id.erudit.org/iderudit/037288ar

DOI : https://doi.org/10.7202/037288ar

Aller au sommaire du numéro

Éditeur(s)

Association canadienne de traductologie

ISSN

0835-8443 (imprimé)

1708-2188 (numérique)

Découvrir la revue

Citer cet article

Hyun, T. (1997). Byron Lands in Korea: Translation and Literary/Cultural

Changes in Early Twentieth-Century Korea. TTR, 10(1), 283-299.

https://doi.org/10.7202/037288ar
Résumé de l'article

Byron en Corée : traduction et changements littéraires/culturels en Corée au tournant du siècle - Cet article étudie le rôle qu'a joué la traduction dans l'émergence de la poésie coréenne moderne. La plupart des chercheurs croient qu'au tournant du siècle, les poètes/traducteurs tels Ch'oe Namson se sont attachés à transmettre davantage le message que la forme. Nous croyons qu'il est nécessaire de reconsidérer le lien étroit qui unit les images et rythmes poétiques créés par Ch'oe et le développement, dans la poésie coréenne des années vingt, de nouvelles formes.
Tous droits réservés (C) TTR: traduction, terminologie, rédaction — Les auteurs, 1997
Ce document est protége par la loi sur le droit d'auteur. L'utilisation des services d'Érudit (y compris la reproduction) est assujettie à sa politique d'utilisation que vous pouvez consulter en ligne.

https://apropos.erudit.org/fr/usagers/politique-dutilisation/ 


\section{Byron Lands in Korea : Translation and Literary/Cultural Changes in Early Twentieth-Century Korea ${ }^{1}$}

\section{Theresa Hyun}

Korea is a particularly good case for the study of the essential role that translation plays in cultural development. As part of the Chinese cultural sphere for centuries, Korean native culture developed alongside a dominant neighboring society. In the seventeenth century, for example, Korean scholars became acquainted with western texts through their Chinese translations. Scholars of the Silhak, or practical learning movement, imported western materials on both scientific and religious topics, including geography, medicine, astronomy and Catholicism ${ }^{2}$. This first phase of the introduction into Korea of certain areas of western knowledge formed the background for the importation of western texts in translation which occurred in the Kaehwa (opening or enlightenment) period in the late nineteenth and early twentieth century.

I This research was made possible by a grant from the Daesan Foundation.

${ }^{2}$ The Silhak movement (seventeenth to nineteenth century) comprised a group of Korean Neo-Confucianist scholars who attempted to go beyond the abstract metaphysical approaches of neo-Confucianism in order to find practical solutions to the agricultural, economic and social problems facing Korea. 
Korean scholars of the Silhak school who visited China in the seventeenth century took a strong interest in the European works available in Chinese translation, and they began to introduce them into their own country. This was instrumental in undermining the traditional Sino-centric world view which had prevailed until then in Korea. In the fifteenth century, the invention of the Korean phonetic script, now known as hangul, had led to the translation of Chinese texts on Confucianism and Ethics into the vernacular in order to propagate Chinese thought and confucianize the country.

The first section of this article outlines the background of translation and cultural change in Korea : 1) the translation of Chinese works and traditional values in Korea and 2) the translation of western works and the transition to modern values. In the second section I deal with the work of Ch'oe Namson, one of the first modern Korean literary translators, and the introduction of some of Byron's works into the country. New spatial images relating to translation contributed on the one hand to the shift from a China-centered to a western-oriented world view and on the other to a change in cultural identity in early twentieth-century Korea.

\section{Background on Translation and Cultural Change in Korea}

\section{1) The Traditional Period}

\section{i) Early Choson}

During the Choson period (1392-1910) Koreans recognized the superiority of Chinese culture and considered themselves to be in a tributary relationship with China. Until 1876, when the Koreans signed their first modern treaty with Japan, Korean foreign relations were centered on China and involved paying tribute to China in return for protection.

In the traditional period, diverse aspects of Chinese civilization were imported into Korea, including the writing system, philosophy, literature and religion. During the Three Kingdoms period (first to seventh century AD) Confucianism, Buddhism and Chinese Civilization were 
accepted first by the elite and then gradually spread to the common people. Korea came to consider herself to be a little China, and the concept that the world could be divided into two groups - the Chinese and the barbarians - was accepted.

After the creation of the Korean phonetic script, hangul, many Chinese texts were translated into the vemacular. By transmitting Chinese thought, these translated texts deepened Sino-centric values, history and ethics to a wider range of people. Among the representative works translated at this time were commentaries on the Chinese classics and other Confucian texts of a pedagogical nature, literary works and Buddhist scriptures. The works of the Tang dynasty poet $\mathrm{Tu} \mathrm{Fu}$, considered by Koreans to represent the virtues of Confucianism, were repeatedly translated throughout the period. At the end of the sixteenth century a fifty-four volume collection of Confucian works appeared in translation. Translators of this period employed a Chinese style which was difficult to comprehend without a knowledge of Chinese characters.

\section{ii) Late Choson}

In China the seventeenth century marked the transition from the Ming to the Ching Dynasty. Although Koreans at first hesitated to recognize the new rulers, who were not ethnic Han Chinese, the technical achievements of the Ching in architecture, agriculture, medicine and mathematics were gradually to have an important influence on Korea. Korean scholars who visited China became acquainted with new forms of knowledge through translations of westem texts into Chinese. The Silhak scholars realized that western science might prove helpful in overcoming the deteriorating economic and agricultural conditions in Choson society.

At first Catholicism aroused interest among Korean scholars, not as a religious dogma but rather as an aspect of the new western knowledge, and was introduced along with texts translated into Chinese on geography, physics, astronomy and medicine. However, eventually Catholicism came into conflict with traditional Korean customs and the 
persecution of Catholics began ${ }^{3}$. Korea entered a period of conflict between traditional and western society which resulted in an official order forbidding Catholicism and banning westem texts. Although the Silhak scholars were convinced of the value of western science, a view of the world centered on China continued to predominate.

Knowledge about geography can illustrate this conflict in values. The Korean concepts of geography were represented by the $C h^{\prime}$ onhado, a map which placed China at the center of the world ${ }^{4}$. One of the early Silhak scholars, Yi Ik (1681-1763), recognized the correctness of the geographical knowledge contained in the western map introduced by Matteo Riccis. However, in spite of this contact with western knowledge, Yi Ik upheld the principle that China occupies the center of the world's surface.

Certain Korean scholars of the next generation went beyond the traditional way of dividing the world between the Chinese and the barbarians. Hong Tae-Yong (1731-83) made six trips to China and engaged in discussions with western missionaries and Ching scholars. Hong came to realize that the idea that China lies at the center of the world was false. This was a step toward a modern scientific approach for the Silhak scholars, who began to comprehend principles such as the rotation of the earth on its own axis. In his Bukhakeui (Northem Learning) Pak

\footnotetext{
${ }^{3}$ Starting in the seventeenth century, westem texts were imported into Korea by emissaries who visited Beijing. Among these texts was Matteo Ricci's True Principles of Catholicism. Some of the Silhak scholars were interested in the new religion and a few were converted. The religion began to spread but it came into conflict with the ruling Neo-Confucian ideology and Catholics were accused of being anti-social. The first official persectrion began in 1791 followed by others in $1801,1839,1846$ and 1866 during which many believers were martyred.
}

"The Ch'onhado was the map traditionally used in China. By placing China at the center of the world, the map indicated that the surrounding peoples were under Chinese domination.

${ }^{5}$ In 1602, Matteo Ricci introduced a map of the world into China. The map, known in Korean as Kenvo Manruk Jido gave details of the five continents and was introduced into Korea the following year by Yi Ik. It greatly influenced the geographical concepts of Silhak scholars. 
Jae-Ga (1750-1805) recommended that Korea overcome her backwardness by inviting western scholars to assist in technological endeavors, as Ching China had done'.

However, Koreans were not able to accept western civilization with such openness until the late nineteenth century. Unlike Ching China, where western religion and civilization were introduced by Matteo Ricci and other European missionaries as a stage in the development of structured scientific knowledge, most of the Silhak scholars remained caught in the dilemma of religion vs. science. In spite of their admiration for some aspects of western science, Korean scholars could not go beyond the limits of their strict Neo-Confucian ideology. Well into the nineteenth century, Korean scholars expressed their suspicion of foreign thought. In the Tongdo Sogi Ron ('Theory of Eastern Ethics and Western Technology), for example, Kim Yun Sik proposed in 1880 that western technology should be accepted while maintaining the superiority of Confucian ethics.

Translations from Chinese into Korean in the late Choson period included works on western science and Chinese literary works. Chinese literature continued to exert a strong influence on Korean writing. Works such as T'aep'vong Kwangoi (Records of the Ancient Chinese Dynasties) and Samguk Ji (History of the Three Kingdoms) were widely distributed in translation and attracted a considerable readership. In contrast to the translations into Korean of the earlier period, those of late Choson aimed at acceptability with the target audience rather than adequacy with respect to the source text. The translation of Chinese literary works thus contributed to the development of writing style in Korean.

\section{2) The Transitional Period}

The study of spatial and geographical images is important for an understanding of the cultural changes which took place in Korea in the

\footnotetext{
${ }^{6}$ Pak Jae-Ga (1750-1805) wrote his representative work, Bukhakeni, after a visit to China. He recommends that the technology of advanced civilizations be introduced to overcome the stagnation of Korean culture, to reform society and to promote commerce and industry. Pak felt that these changes would contribute to the well-being of the common people.
} 
late nineteenth and early twentieth century. Starting in 1880, translations of western texts on world geography began to appear. Conservative members of the government had suppressed the world map brought by European missionaries to China since they feared the new ideas would be subversive to the Neo-Confucian philosophy of the elite group. Therefore the first modern Korean newspapers were quite innovative when they began introducing facts about world geography in the 1880s. One of these publications, the Hansong Jubo, published articles explaining in detail about the continents and the traditional customs of the people of various regions of the world. These articles were accompanied by maps of the eastern and western hemispheres. The early modern newspapers went beyond the traditional view placing China at the center of the universe and contributed to educating Koreans about their place in the world.

Much of the pressure to reform and modernize was put on the conservative Korean government by members of the upper-class, who were influenced by the westernization movement in Japan. Proponents of what Koreans called "enlightenment thought" advocated equality, the abolition of class distinctions and political reform along the lines of what was taking place in Japan. During the transitional phase from traditional to modern values, most foreign material came into Korea by indirect translation, mostly by way of Japan. Japan was therefore replacing China as the intermediary in the importation of western culture into Korea. Translation of educational material contributed greatly to the shift from Sino-centrism to a broader world view. The fact that the dominant position of Chinese culture had become an anachronism was illustrated by the replacement of the traditional China-centered maps by new ones, in which China occupied one segment of the globe.

In addition to newspapers, educational texts of the period, such as Samin P'ilii (Essential Knowledge for Scholars and Common People), also focused on geography. In the introduction of this text, written in 1895 in pure hangul, the author emphasizes the importance of knowledge about geography for modern citizens and gives an overview of world civilization. This work relied heavily on translation and aimed to help Koreans broaden their knowledge of the world, with sections on the continents and details for each region concerning climate, production, topography and other topics. The western style educational institutions 
which began to appear around the turn of the century taught Korea's place in world geography, using texts which were also based on translations.

\section{Ch'oe Namson, Byron and the New Sea Imagery}

Ch'oe Namson, one of Korea's first modern literary translators, displayed a keen interest in geography. The work of this early twentieth-century translator is extremely instructive for an understanding of the relation between translation and the changing cultural identity in Korea. Ch'oe was bom in $\mathbf{1 8 9 0}$ to a middle-class family, and made two brief trips to Japan, first in 1904 to attend a Tokyo middle-school, and again in 1906 to attend Waseda University. At this time Ch'oe came into contact with western cultural and literary trends in the already modernized Japan.

In Japan the Meiji Restoration had begun in 1868, although importation of western ideas during the preceding period had prepared the way. Already in the eighteenth century certain Japanese scholars had translated Dutch texts in order to transmit knowledge about the western world. But it was not until the opening of Japan to the West in the 1860s that revolutionary changes took place. In the early 1870 s the government dispatched envoys to Europe and the United States to observe the workings of western civilization. Fukuzawa Yukichi's book Seiyo Jijo (Conditions in the West), 1866-70, in which he recounts his observations during travels to Europe and America, is said to have sold over 200,000 copies. During the following decades various aspects of Japanese culture were reorganized according to western models. At this time modern notions of literature began to replace traditional forms : Japan's traditional reverence for Chinese culture was replaced by an infatuation with all things western. When Ch'oe was in Japan at the turn of the century, three major books of modern poetic translations into Japanese had already appeared : Shintai-shisho (Anthology of New Style Poems), 1882; Omakage (Shadows of Remembrance), 1889; and Kaicho-on (Sound of the Tide), 1905.

When Ch'oe returned to Korea, he felt he had a mission to enlighten his young countrymen and thus embarked on the publication of a joumal, Sonyon (Youth), 1908-11, to educate patriotic youths who would build a modern nation. Excerpts from the works of authors such as Byron, Tennyson, and Tolstoy were translated, from Japanese translations, 
to awaken young people to the world beyond their own nation. Thus, at least until the $1920 \mathrm{~s}$, translation in Korea still depended heavily on indirect translation. Of the ten translated poems appearing in Sornon eight were translated by Ch'oe. There is some evidence that Ch'oe was referring to a Japanese anthology of translated poems when he did his translations for Sonvon. The anthology, Selections from a Hundred British and American Poets, appeared in Japanese in Tokyo in 1908. Scholars advance the following connections between Ch'oe's translations and those appearing in the Japanese anthology : 1) the Japanese anthology came out in July 1908 and was available in Korea before Somvon first appeared in November 1908; 2) all of the poems that Ch'oe translated appeared in the Japanese anthology, and 3) a comparison of Ch'oe's translations with those of the Japanese anthology reveal close similarities in terms of diction and poetic form, including the use of the seven-five syllable pattern common to Japanese poetry but not often used in Korean poems before this time (Kim Byong-Ch'ol, 1975, p. 293).

The image of the ocean which appears in Sonvon indicates one of the ways in which translation related to the formation of a new cultural identity in early twentieth-century Korea. The ocean is not a common theme in traditional Korean poems. When sea imagery does appear in traditional poems it is connected with loneliness, alienation and possibly even exile. During the traditional period the political, social and economic life of the country was centered on the capital city, located inland. Therefore the sea symbolized alienation as it was far from the center of civilization. As already pointed out the traditional Korean world view was centered on China, which means that cultural influences came by land rather than by sea. In fact practically the only positive image of the sea comes from folk legends of the Kingdom of the Dragon King, located at the bottom of the ocean.

The poem "Blue Rapid and Moon" by the sixteenth century poet Whang Jinnie exemplifies traditional sea imagery. In this Sijo the sea represents a place from which one can never return :

The blue rapid runs through green gorge,

Boast not dear, how sleekly you flee

You'll never come back again

Once you reach far into the sea 
Full moon shines upon us so fresh

Relax awhile, play with me. (Kim Unsong, 1986, p. 160)

Ch'oe's original poem "Haeegeso Sonyonege" (From the Sea to the Boys) appeared in the first issue of Sonyon published in November of 1908. This poem displays a diversity of techniques and rhythmic patterns in its six stanzas. Some praise it as being the first truly modern Korean poem, while others have considered the work as being problematic because it seems to have appeared abruptly with all its daring poetic innovations. Some scholars consider it to have been an imitation of Byron's "Ocean". It is best to study this poem as an outgrowth of Ch'oe's poetic experiments which began in 1907 when he was an exchange student in Japan. About this early period of poetic experimentation Ch'oe wrote :

I am not by nature a poet. However, the situation of the times and my circumstances continually tried to make me one. Thus, three months before the Chongmi treaty was concluded, I took up a pen and happened to record what I had been thinking. With this start I produced a dozen pieces in three or four months. This was at once the beginning of my writing poems and the start of testing the forms of new Poems in Korea. (Sym, 1982, p. 82)

The Chongmi Treaty was concluded between Korea and Japan in 1907 and was part of the process of Japan's colonial take-over of Korea, which was completed in 1910 . The circumstances which finally made Ch'oe turn to writing poetry were those of a young student attempting to arouse his countrymen about the need to modernize and defend their nation.

Ch'oe's poems of the period range from conventional poetic form to modern free verse and prose poems. The six stanzas of "From the Sea to the Boys" display a kind of wave rhythm alternating long and short lines. The opening and closing lines of each stanza employ onomatopoeia to imitate the sound of waves crashing on the shore. The poem is a kind of eulogy by the sea in praise of the daring and innocent boys.

Though all men on earth are hateful, I have only one thing I love among them : It is that daring and innocent children 
Lovingly come, as if in sweet play, into my bosom.

Come, children, and I will kiss you. (Sym, 1982, p. 99)

In the end the emphasis of the poem is on the praise of the "daring and innocent children". Written by a young man of eighteen the poem is a call to his youthful countrymen to embrace change in order to strengthen their nation. From the point of view of form the poem continues the experiments with versification which Ch'oe had begun in some of his earlier poems and which he would pursue for the next several years.

Another example of an experimental poem in which Ch'oe combines the imagery of the sea which brings renewal and the young boys who are to lead their nation, is "Pada uie Yong Sonyon" (Brave Young Boys on the Sea). Consisting almost entirely of four-five syllable rhythm groups, this poem appeared in the November 1909 issue of Sonvon. Although it is somewhat monotonous compared to the earlier poem it contains some lines designed to arouse patriotic feelings in the youth of Korea :

These three young boys are children of the sea

Of all the many lives on Korea's path

They are the greatest, most sacred and bravest children.

(translated by Theresa Hyun)

These works represent a trend in Ch'oe's writing to employ new sea images and break away from traditional forms which consisted mostly of groups of three-four syllables. We will see how this trend was reinforced through his work as a translator.

I would now like to look briefly at segments of two of Byron's poems as examples of the ways in which literary forms and cultural images were changed through translation.

The two translations in question are Ch'oe's translation of the first section of the opening Canto of Byron's "The Corsair", and the translation of stanzas 179 to 184 from the fourth Canto of Byron's "Childe Harold's Pilgrimage". The translator of the segment from "Childe Harold's Pilgrimage" is listed only by the nom de plume of "Orang". This mysterious designation cannot be identified with any of the literary figures of the time in Korea. We cannot say for sure that Ch'oe himself was the 
translator of this poem. However, as we will see, these two translations follow different norms.

What follows are a few lines of the originals along with my renderings back into English of the translations, as a brief illustration of competing strategies of translation at that time.

"The Corsair" Canto the First I (Byron)

"Haejok ga" (Song of the Corsair) translated by Ch'oe Namson

Byron : These are our realms,

Ch'oe : Truly these are our realms

B : no limits to their sway-

C : We never had reason to go

B : Our flag

C : Our flag once flies

$B$ : the sceptre all who meet obey.

$\mathrm{C}:$ There is nothing which doesn't fall

B : Ours the wild life

C: Our rugged life

B : in tumult still to range

C : It isn't that it is not uproarious

B : From toil to rest,

C : After hard work rest comfortably

$B$ : and joy in every change.

C : Do something different every time feel joyful.

(More, 1933) (Ch'oe, 1910.3.15, p.4)

"Childe Harold's Pilgrimage" Canto the Fourth CLXXIX (Byron)

"Tae Yang" (Ocean) translated by Orang

Byron : Roll on, thou deep and dark blue Ocean, roll!

Orang : Roll, you deep and jet-black Ocean, roll 
B : Ten thousand fleets sweep over thee in vain

$\mathrm{O}$ : Ten thousand warships over you rush in vain

B : Man marks the earth with ruin, his control

$\mathrm{O}:$ Man perhaps on the earth trivial trace leaves

B : Stops with the shore; upon the watery plane

$\mathrm{O}$ : His strength only to the shore comes and stops

B : The wrecks are all thy deed, nor doth remain

$O$ : On the vast water all your deeds exist

B : A shadow of man's ravage, save his own,

$\mathrm{O}$ : Man's destruction not even a tiny trace leaves only his own

B : When, for a moment, like a drop of rain,

$O$ : Indeed man for a little while rain like one drop in your deep water falls

B : He sinks into thy depths with bubbling groan,

$\mathrm{O}$ : Foam spewing forth laboring, sinking

B : Without a grave, unknell'd uncoffin'd, and unknown.

$O$ : Without a grave, without a mourning bell, without a coffin, there perishes.

(More, 1933) (Ch'oe, 19106.15 p. 5)

If we examine Ch'oe's translation of Byron's "The Corsair", we can see Ch'oe was not following the original closely. Rather, scholars agree that he was following the Japanese translation very closely even to the point of imitating the seven-five syllabic rhythm pattem, which was not common in traditional Korean poetry?. In fact Ch'oe goes so far as to acknowledge in a note at the end of his translation that he was referring to a Japanese translation of Byron's poem.

The translation of Byron's "Childe Harold's Pilgrimage" displays some marked differences from Ch'oe's translation of "The Corsair". We

${ }^{7} \mathrm{~A}$ detailed treatment of the adoption of the traditional Japanese seven-five syllable poetic rhythm pattern in modem Korean poetics is given by Kim Jun-Oh (1984, pp. 100-103). 
can see that the translation follows the English original more closely. The translator does not imitate a set rhythmic pattern. The fact that the six stanzas from Byron's original poem are included with the translation was quite unusual for the time and would seem to indicate that the translator was translating directly from the original. Few Korean translators at the turn of the century were capable of translating directly from western languages.

What can be concluded from these few examples of translations of Byron's works at the turn of the century in Korea taken as illustrations of the relationship between translated and original writings at the time? First it should be noted that at this time translation into Korean of western works was at a very preliminary stage and consisted of excerpts or summaries for the most part translated indirectly through Japanese translations. This much is generally agreed upon by scholars of Korean literature. Furthermore, those scholars believe that in the early period both translations and original works aimed at transmitting a message of social edification and were not concerned with questions of form. The examination of Ch'oe's work as poet and translator, however, shows the necessity of revising the formulation of the relationship between translated and original writings in Korea. Far from being unconcerned with form, experimentation with new rhythmic patterns was one of Ch'oe's main preoccupations at the time he was publishing his journal Sonvon. Although some scholars have held that Ch'oe modeled his original poems on translations of Byron's works, Ch'oe's "Sea" poems appeared before the Byron translations.

It is significant that Ch'oe's translation of "The Corsair", whatever might be said about its accuracy, displays the same concern with thythm patterns that is evident in his original poems. Of these four works, the translation of "Childe Harold's Pilgrimage" was the last to appear and was not signed by Ch'oe.It may not be possible to prove conclusively who the translator was, but it seems clear that it adopts an approach to translation which was less influential at that particular moment in Korean literary history. Rather than aiming at accuracy in terms of the source text, or attempting to import poetic models directly from the west, Ch'oe represents a trend of breaking with traditional form in order to create images of cultural renewal. Byron and other westem authors were first 
imported into Korea in translation to support this trend of formal innovation and new thought patterns.

Ch'oe Namson translated western poetry dealing with the sea, with the intention of introducing new images of purity and absolute freedom. When he wrote the first modern Korean poem praising the ocean, "From the Sea to the Boys", he was breaking with Korean poetic traditions. In this poem the young gain strength from the sea to break with old customs and this brings new ways of thinking. In Ch'oe's early work the sea symbolized modernization, as well as the endless hope of creating a new world and of heading toward a new era. However, gradually sea imagery lost its importance in Ch'oe's work. This was perhaps partially due to the realization that modernization was not without pitfalls for the Korean people. Nevertheless at the turn of the century the sea provided an image of cultural renewal which infused both translated and original poetry in Korea.

\section{Concluding Remarks}

I would like to add a few final comments about the generation of literary translators who followed Ch'oe Namson. Translation in early modern Korea may be divided into the following periods : 1) a preparatory phase from 1895 to 1917 ; 2) next, the point when translation norms began to crystallize from 1918 to the mid-1920s; and 3) a period of increasingly specialized translation from the mid-1920s to the mid-1930s.

The work of Ch'oe Namson falls into the earliest period characterized by the impact of the importation of western culture. Most of the translation activity of this period was undertaken for political and social purposes, to encourage patriotism and aspirations for independence. However, as we have seen, although Ch'oe and other early translators published mostly indirect translation based on summaries, adaptations or parts of works, their experiments with form and attempts to create new images prepared the way for the next generation of translators.

The work of poet/translator $\mathrm{Kim}$ Ok was seminal during the formative period of modern Korean poetic forms in the 1920s. His translations of the works of western poets, especially symbolist poets like Verlaine and Baudelaire, constituted attempts to create new poetic 
mythms. While it is generally recognized that Kim Ok helped bridge the gap between the early period of translation for pedagogical purposes, and the literary translators of the $1920 \mathrm{~s}$, his debt to the formal and thematic innovations of Ch'oe's translations cannot be ignored.

As research in the field progresses it would be worthwhile giving further consideration to questions raised in this article concerning the essential role of translation during the formative phase of modern Korean poetry. First, it would be useful to re-examine the connection between the experiments in poetic form by Korean translators at the turn of the twentieth century and the development of modern forms which began in the 1920 s and 30s. Second, the widely accepted dichotomization of Korean poetry of the early twentieth century into 1) poetry before 1920 delivering a message of social improvement without attention to technique, and 2) poetry after 1920 focusing on aesthetic concerns and imported new moods and images through translation of foreign poetry should be revised. More detailed comparative studies linking the work of poet/translators from Ch'oe Namson through Kim Ok and into the 1920s and beyond are needed. This preliminary exploration of translation and the new poetry of the early twentieth century in Korea can lead to a better understanding of the development of modern Korean poetic forms as well as a refinement of approaches to the study of translation and literary and cultural change.

York University

\section{References}

BANG, Dong-In (1975). Hangukeui Jido (Maps of Korea). Seoul, Kyoyang guksa Ch'ongso.

CHO, Dong-Il (1994). Hanguk Munhak Tongsa (History of Korean Literature). Seoul, Jisik Sanopsa.

CH'OE, Namson (1908-1910). Sonyon (Youth), Seoul.

HANGUK Chonch'i Oegyosa Hyophoe (1993). Hanguk Oegyosa I (Korean Diplomatic History). Seoul, Jipmun Dang. 
HERMANS, Theo, ed. (1985). The Monipulation of Literature : Studies in Literary Translation. London, Croom Helm.

HYUN, Theresa (1992). Translation and Early Modern Korean Literature. Seoul, Siwa Sihaksa.

HYUN, Theresa and LAMBERT, José, eds. (1995). Translation and Modernization, Tokyo, University of Tokyo Press.

JANSEN, Marius B. (1995). The Emergence of Meiji Japan. New York, Cambridge University Press.

JO, Yun-Jae (1984). Hanguk Munhaksa (History of Korean Literature). Seoul, Tamgu Dang.

KANG, Jae-Un (1990). Chosoneui Sohaksa (History of Catholicism in Choson). Seoul, Daewoo Haksul Ch'ongso.

KIM, Byong-Ch'ol (1975). Hanguk Kundae Bonyok Munhaksa Yongu. (History of Literary Translation in Modem Korea). Seoul, Ulyu Munhwasa.

KIM, Jaihiun J., trans. (1980). Master Poems from Modern Korea Since 1920. Seoul. Si-sa-yong-o-sa.

KIM, Jun-Oh (1984). Poetics of Identity. Seoul, Munjang.

KIM, Ok (1923). Haep'arieui Norae (Song of the Medusa). Seoul.

KIM, Unsong, trans. (1986). Classical Korean Poems (Sijo). Seoul, Il Nyum.

KIM, Yol-Kyu, and SHIN, Song-Uk, eds. (1986). Ch'oe Namsongwa $Y_{i}$ Kwang Sueui Munhak (The Literature of Ch'oe Namson and Yi KwangSu). Seoul, Saemunsa.

KIM, Yoon-Sik, ed. (1984). Ch'oe Namson, Kim Ok. Seoul, Jisik Sanopsa. 
LEE, Ch'an (1970). Hanguk Jirihaksa (History of Korean Geographical Studies). Seoul, Koryo Taehakkyo Minjok Munhwa Yonguso.

LEE, Kyong-Son (1988). Hanguk Munhakgwa Jont'ong Munhwa (Korean Literature and Traditional Culture). Seoul, Singu Munhwasa.

MORE, Paul E., ed. (1933). Complete Poetical Works of Byron. Cambridge Edition.

SYM, Myung-Ho (1982). The Making of Modern Korean Poetry : Foreign Influences and Native Creativity. Seoul, Seoul National University Press.

TOURY, Gideon (1980). In Search of a Theory of Translation. Tel Aviv, Porter Institute for Poetics and Semiotics, Tel Aviv University.

RÉSUMÉ : Byron en Corée : traduction et changements littéraires/culturels en Corée au tournant du siècle - Cet article étudie le rôle qu'a joué la traduction dans l'émergence de la poésie coréenne modeme. La plupart des chercheurs croient qu'au tournant du siècle, les poètes/traducteurs tels Ch'oe Namson se sont attachés à transmettre davantage le message que la forme. Nous croyons qu'il est nécessaire de reconsidérer le lien étroit qui unit les images et rythmes poétiques créés par Ch'oe et le développement, dans la poésie coréenne des années vingt, de nouvelles formes.

ABSTRACT : Byron Lands in Korea : Translation and Literary/Cultural Changes in Early Twentieth-Century Korea - This article deals with the role of translation during the formative phase of modern Korean poetry. Most scholars think that the work of poet/translators of the early twentieth century like Ch'oe Namson emphasized transmitting a message rather than technique. I assert that we need to re-examine the crucial relationship of the new poetic rhythms and images used by Ch'oe and the development of modern Korean poetic forms in the 1920s.

Theresa Hyun : Division of Humanities, York University, 4700 Keele St., North York, Ontario M3J 1P3. Tel and Fax: (416) 538-9229. 